\title{
FACTORS THAT INFLUENCED PEOPLE TO BECOME ISLAMIC BANK CUSTOMER: A STUDY ON KANCANA VILLAGERS
}

\author{
Indah Mulia Sari, Hendro Wibowo \& Edy Suprapto ${ }^{1}$
}

\begin{abstract}
Factors That Influenced People To Become Islamic Bank Customer: A Study on Kancana Villagers. Islamic finance and banking industry in Indonesia has shown a significant growth, average growth of $30 \%$ more per year in the last five years, with a total number of Islamic banks customers as much as 12 million accounts, or market share 4.8\%. In this study, researchers attempt to describe the events in rural districts West Java related to the factors that influence people to become customers of Islamic banks. Data processing by tabulation and scoring and based on the analysis and discussion are carried out. The results of this study indicate that the Islamic bank customers' data are mostly women in productive age with maximum a senior high school education and their profession up mostly are traders. Others reasearch results related to factors which influence people to become customers of Islamic banks were influenced by psychological, social, personal, economic and cultural factors.
\end{abstract}

Keywords: Islamic Banking and Finance, Islamic Bank Customers, Consumer Behavior

\begin{abstract}
Abstrak. Faktor-faktor Yang Mempengarubi Seseorang Untuk Menjadi Nasabah Bank Syariab: Studi pada Penduduk Desa Kancana. Industri keuangan dan perbankan Islam di Indonesia telah menunjukkan pertumbuhan yang signifikan, rata pertumbuhan mencapai $30 \%$ lebih pertahun dalam lima tahun terakhir, dengan jumlah total nasabah bank syariah sebesar 12 juta rekening atau market share mencapai 4.8\%. Dalam penelitian ini, penulis mencoba untuk menggambarkan peristiwa di Pedesaan wilayah Jawa Barat terkait dengan faktor-faktor yang mempengaruhi orang untuk menjadi nasabah bank syariah. Pengolahan data dilakukan dengan tabulasi dan scoring dan berdasarkan analisis dan pembahasan yang dilakukan. Hasil penelitian ini menunjukkan bahwa data nasabah bank Islam sebagian besar perempuan di usia produktif dengan maksimal pendidikan SMA dan profesi mereka sampai sebagian besar adalah pedagang. Hasil lain penelitian adalahterkait dengan faktor-faktor yang mempengaruhi orang untuk menjadi nasabah bank syariah dipengaruhi oleh faktor psikologis, personal, faktor sosial ekonomi dan budaya
\end{abstract}

Kata Kunci : Keuangan dan Perbankan Syariah, Nasabah Bank Syariah, Perilaku Konsumen

First draft: September, 10th 2014, Revision: November, 25th 2014, Accepted: December, $10^{\text {th }}$

1 SEBI School of Islamic Economic, Address :Bojong Sari Street Depok West Java, Indonesia Email: muliasari.indah@gmail.com; hendro.wibowo83@gmail.com; edy.suprapto77@gmail. 


\section{Introduction}

Islamic finance and banking industry in Indonesia has shown a significant growth. Its development has reached an average growth of $30 \%$ more per year in the last five years. This figure is above the average growth of Islamic banking industry in the world which is only $10 \%$ to $15 \%$ per year. In fact, this growth rate is also higher than the average growth of the national banking industry, recorded an average of $16.7 \%$ per year. Similarly, other Islamic financial industry (Islamic capital market and Non-Bank Financial Institutions) experienced rapid growth although not as fast as the Islamic banking industry.

Formally, the developmentof Islamic banking in Indonesia has entered a period of 22 years starting in 1992 to the present. Based on Islamic Banking Statistics data as of December 2013, the growth Islamic banking assets which consist of Islamic Commercial Banks (ICB) and Islamic Business Unit (IBU) increased from Rp 195 trillion in 2012 to Rp 242 trillion in 2013, increased by 24\%. Meanwhile, the volume of financing in the same period has reached Rp 184 trillion (growing 25\% -yoy) from the previous year 2012 which amount to Rp 147 trillion and third-party funds that is achieved by the Islamic banking amounted to Rp 183 trillion (growing $24 \%$-yoy) from the previous year 2012 which amount to Rp147 trillion. For over the last five years, it has witnessed the growth rate of Islamic banking, both in terms of assets, financing and third-party funds showed an upward trend.

As we all know that the majority of Indonesia's population is Muslim. It has become a necessity for Muslims to use Islamic principled financial services. Moreover, the current development of Islamic banking in Indonesia from year to year is quite significant. Thus, there is no longer any reason for the Muslim community not to use the services of financial institutions in accordance with Islamic principles. The reality has shown that the number of customers of Islamic banks has increased in significant numbers.

The data shows that the trend of growth in the number of customers increased year-over-year in average of 26\%. The most significant growth trend shows in 2011 by $35 \%$, despite the fact of a $20 \%$ downturn by the end of 2013 , so that only grow on range of $11 \%$ away from the previous year in 2013 the trend growth of Islamic banks customers by $32 \%$. With a total number of Islamic banks customer's as much as 12 million accounts, it only reached $4.8 \%$ of the total population of Indonesia at the end of December 2013 amounted to 248 million people (Statistic Indonesia, 2014).

Various factors can affect one's lifestyle including demographics, personality, social class, and life cycle in the household. Each person certainly has their own 
reasons. Therefore, factors that underlying decision made by the District Cikijing Kancana villagers to become an Islamic bank customers still an interesting topic to examine.

From the above background, the formulation of the problem which is used to conduct this research: first, how are the characteristics of the District Cikijing Kancana villagers? Second, what factors are affecting the District Cikijing Kancana villagers to become customers of Islamic banks?

Given the extent of the topic about the community and the banking institutions, this paper limit the issues in this research are as follows: first, this research focuses on factors that affect the District Cikijing Kancana villagers to become customers of Islamic banks; second, Object of this research is the District Cikijing Kancana villagers who become bank's customer in the District Cikijing.

\section{Literature Review}

There are several definitions of consumer behaviour according to some marketing experts: Consumer Behaviour is "The study of individuals, groups or organizations and the processes undertaken in selecting, determining, obtaining, using, and discontinue using the products, services, experiences, or ideas to satisfy needs and the impact of these processes on consumers and society "(Hawkins, et.al. 2001). Consumer behaviour also can described as the mental and physical activity undertaken by household customers (end consumers) and business customers that result in a decision to pay, purchase, and use of certain products and services (Sheth \& Mittal, 2004).

Based on those five standpoints regarding the definition of consumer behaviour, it can be summarized that consumer behaviour is a process undertaken by individuals / consumers in making decisions, both in the pre-purchase, purchase and post-purchase.

Consumer behaviour model was used as an effort to make it easier to understand consumer behaviour. A model is a simplification of the true picture (Swasta \& Handoko, 2000). This simplification through setting aspects of reality and only consists of the aspects that make keen to the model maker (Swasta \& Handoko, 2000). For example, if the intention is to interpret consumer behaviour as a decision-making process, the emphasis of the model is the process. The form of the model may vary, the model can be a verbal description, or by using mathematical symbols. Most of consumer behaviour model described verbally.

Consumer behaviour will determine the decision-making processing purchasing. The purchasing process consists of fivesteps: first, needs identification; 
second, search for information; third, evaluate the information; fourth, purchase decision; fifth, post-purchase behavior. The Overall process explained above is only occurred in certain circumstances, for example at the first purchase. This means that the entire above process is not always done by the consumer. Consumers will be easier to take a decision in there-purchase or continuity in nature or in other words, if consumers are satisfied then they will not undertake initial process, they maybe immediately go to purchase decision process.

The purpose of marketing activities is to influence consumers to buy certain goods or services. It is very important for marketing managers to understand why and how consumer behaviour so that the company can develop, pricing, promoting, and distributing its products better. By studying the consumer behavior, managers will know what the unmet wants and needs of their consumers so that they can identify it to make market segmentation.

Next, we will explain about Islamic Bank. Islamic bank is a bank that is running its operations based on Islamic principles and by the type it consists of Islamic Commercial Banks (ICB) and Islamic Rural Banks (IRB). Islamic bank got the legitimacy from the Indonesian government with the passage of the Islamic Banking Act No.21 of 2008, on July 16, 2008. In Islamic banking Act no.21, 2008 the term of Islamic Credit Bank was changed to Islamic Finance Bank. This change made in order to emphasize the differences between credit and financing based on Islamic principles.

According Triandaru and Budisantoso (2006), Islamic bank is a bank that its activities, both fund raising and distribution of funds provide there ward on the basis of Islamic principles, namely buying and selling and profit-sharing. Islamic Bankis an intermediary institutions and financial service providers who work one thics and value system of Islam, especially free from interest, free from nonproductive speculative activities such as gambling (masyir), free from the things that are not obvious and dubious (gharar), the principleof justice, and only pay for the lawful business activities. Islamic banks actively participate in achieving the goals and objectives of Islamic economics-oriented social welfare.

In determining the price or profit for the Islamic principles based bank are as follows: first, Financing is based on the principle of profit sharing (Mudharabah). Second, financing Based on the principle of equity (Musharaka). Third, the principle of trading to make a profit (murabaha). Fourth, lease financing of capital goods based purely without choice (ijara). Fifth, with the choice of the transfer of ownership of the goods are leased from the bank by the other party (ijara wa aqtina) 


\section{Methods}

This research is descriptive research, this means researcher sought to describes or depicts a social situation in broad and deep scope (Sugiyono, 2008). In this study, researchers attempt to describe the events in rural districts Cikijing Kancana related to the factors that influence people to become customers of Islamic banks, then processed and analyzed using descriptive quantitative analysis method. The research was conducted in the village of Kancana the Cikijing District, Majalengka, West Java.

Questionnaires distributed to Kancana villagers by using a list of statements concerning the factors that affect the community in becoming customers of Islamic banks. Answer or assessment from respondent were compiled in frequencies table, then interpreted and analyzed based on the data analysis techniques, and the next process is discussing the result to determine a general overview of research results.

Based on the factors that influence people to become customers of Islamic banks, therefore the two variables are the development of variables into sub-variables and indicators as contained in the following table:

Table 1. Variable, Sub Variable and Indicators

\begin{tabular}{|c|c|c|}
\hline Variable \& Variable Concept & Sub Variable & Indicator \\
\hline $\begin{array}{l}\text { Factors that Influenced } \\
\text { Customers }\end{array}$ & $\begin{array}{l}\text { 1. Culture Fac- } \\
\text { tor }\end{array}$ & $\begin{array}{ll}\text { a. } & \text { Culture } \\
\text { b. Subculture } \\
\text { c. Social Class }\end{array}$ \\
\hline \multirow[t]{2}{*}{$\begin{array}{l}\text { "Kotler (2000) state that } \\
\text { factors that influenced } \\
\text { consumer behavior namely: } \\
\text { culture, social, individual } \\
\text { and psychological factors. } \\
\text { (Simamora, 2002) }\end{array}$} & $\begin{array}{l}\text { 3. Individual } \\
\text { Factor }\end{array}$ & $\begin{array}{l}\text { a. Refference Group } \\
\text { b. Family } \\
\text { c. Role and Status } \\
\text { a. Age and Lifecycle } \\
\text { Phase } \\
\text { b. Job } \\
\text { c. Economy } \\
\text { d. Lircumstances } \\
\text { e. Personalities and } \\
\text { Individual Concepts }\end{array}$ \\
\hline & $\begin{array}{l}\text { 4. Psychological } \\
\text { Factors }\end{array}$ & $\begin{array}{l}\text { a. Motivation } \\
\text { b. Perseption } \\
\text { c. Knowledge } \\
\text { d. Attitude and Trust } \\
\text { e. Education }\end{array}$ \\
\hline
\end{tabular}

Source : Data Modified by authors, 2014 
Data processing is a process in order to gain the summary of data or figures by applying certain methods or formulas. Tabulation is table construction process, containing the data that have been coded according to the analysis required. The process of determining the score of the respondent answers conducted by making classifications and categories that match depends on the assumptions or opinions of respondents. Calculation of scoring is done by using a Likert scale.

Stages in analyzing the data is as follows: Likert scale used to measure the attitudes, opinions and perception of a person or group of people about social phenomena. In this study the likert scale is used to measure the attitudes and perceptions about the factors that influence people to become customers of Islamic banks. Based on the respondents' answers, on the next phase we need to interprete those answers. Distributed questionnaires carried out using a Likert scale, the index scores were obtained as follows: Based on the answers of the respondents will then be obtained on the respondents' answers. Questionnaires were distributed performed using a Likert scale, the index scores were obtained as follows:

Table2. Score Interpretation Criteria

\begin{tabular}{cll}
\hline Likert Score & \multicolumn{1}{c}{ Score } & \multicolumn{1}{c}{ Criteria } \\
\hline 1 & Number $0 \%-20 \%$ & Worse \\
2 & Number $21 \%-40 \%$ & Bad \\
3 & Number $41 \%-60 \%$ & Adequate \\
4 & Number $61 \%-80 \%$ & Good \\
5 & Number $81 \%-100 \%$ & Very Good \\
\hline
\end{tabular}

Source :(Riduwan, 2006)

Once the data is collected through a questionnaire then the next step is to tabulate, which gives the value of the system in accordance with applied. Data analysis was performed in this study by using quantitative and technical analysis using Likert scale.

\section{Discussion}

In this study, the authors distributed questionnaires to Kancana villagers. The identity of the respondents include gender, age, education, home status, employment and incomeof the respondents. By gender, the percentage of women is $70 \%$, and the percentage of men with $30 \%$. This is becauseof the respondents, most women who like to engage in financial transactions with the bank. Women in the village Kencana have more sparetime than men. Therefore, women that more frequently interaction with the bank. Compared with men who generally do not have enough time to deal 
with the bank, and they preferred to trust his wife. Majority of people who become customers of a bank: 34\% of respondents aged 21-30 years, 30\% of respondents aged 31-40 years, and respondents aged $41-50$ by 23\%. Compared to respondents aged 51-60 years 10\% and the percentage of respondents aged $<20$ years numbered 1 person with the percentage of $3 \%$. This shows that age is the productive age, so that the respondent wishes to investor become customers of the bank to prepare for the needs in the future. The majority of respondents that become customers of the bank: 46\% graduated high school (SMA), 23\% graduated from junior high school (SMP), 17\% graduate bachelor degree (Sarjana), and graduated from elementary school (SD) and vocational (Diploma) 7\% respectively. The education level of high school (SMA) graduates have a high percentage, it is because the majority of the villagers are high school (SMA) graduates. In this case meant the whole society Kancana already own their home, or none of the mareleased/rented house. This is because a home is very important to have for the people Kancana. And another thing because urban areas Kancana not familiar with the culture of the lease/contract.

The majority of people who become bank's customers are dominated by people who work as self-employed is $57 \%$. This is because most people Kancana worked as a businessman. They can create their own jobs, and not a few of the mareable to provide jobs for other communities. Furthermore, the 13\% of civil servants, private sector employees is $10 \%$. Other work amounted to 6 people with a percentage of $20 \%$. For employees of SOEs $0 \%$, this is because people are not background by higher education, therefore Kancana community until 2013 no one has worked in SOEs. In data the majority of income communities < Rp. 2,200,000 (fifty percent), 23\% are the people incomes Rp. 2,200,000-5,000,000, and 27\%

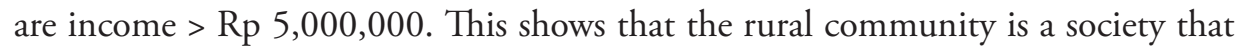
is able to be customers of the bank. Although more than 30 respondents are people who earn less than Rp 2,200,000, but they can set aside money for savings in the bank. This is because the expenditure villagers still are manageable.

Community in the Village of Kancana provide feedback related to the factors that influence people to become Islamic bank's customers. The public response to the factors that influence people to become Islamic bank's customers are described as follows: first is the cultural factor. That of the sub-variable cultural factors, public response from the respondents in the indicator cultures, the majorityof people who claim not agree as much as 44\%, 23\% respondents is agreed, 17\% respondent is sun decided, and the $13 \%$ percentage of respondents strongly disagree of respondents stating and very much as 3\%. It is addressed that the majority of the villagers of Kancana are less affected by the culture there. Therefore the majority of the Kancana's villagers, culture are not a determinant of desires and behaviours 
of the most fundamental. Data can be seen that the variable factors of subcultures, peoples answers on indicators of subcultures, the majority of people who expressed strongly agree with the percentage of $36.67 \%$. Respondents who had agreed were $23.3 \%$, the public chose Islamic banks because of its recognition of the Islamic religion, some people claim Islam as their religion then they should choose a system of Islamic banking institutions. Then $20 \%$ disagree and $13 \%$ of respondents stated strongly disagree. This is because they are already accustomed to using conventional banking services. And $6.7 \%$ of people undecided because respondents could still be influenced or not have a definite choice. It can be seen that the variable factors of subsocial classes, peoples answers located on indicators of social class, the vast majority of states do not agree $40.0 \%$ and $10 \%$ expressed strongly disagree, it shows that according to this respondent does not affect their social class in choosing to become a customer. Compared with people who agree and strongly agreed that states $26.7 \%$ and $16.7 \%$. This shows that the majority of the Kancana villagers are not affected by their sociall class, as agreed percentage is much lower compared with those not agree.

Table 3. Recapitulation of Cultural Factors

\begin{tabular}{|c|c|c|}
\hline No & $\begin{array}{c}\text { Remarks } \\
\text { Sub-Factors }\end{array}$ & Mean \\
\hline 1 & Culture & 52.0 \\
\hline 2 & Sub-Cultural & 70.0 \\
\hline 3 & Social Classes & 62.0 \\
\hline
\end{tabular}

Source : Data processed by authors, 2014

From Table 3, it can be seen recapitulation of cultural factors. The highest indicator of respondents' answers is the sub-culture items with an average value of 70.0 , then the sub-cultures including good category. This indicated that the village communities affected by the culture there in becoming customers of Islamic banks. For the culture itself that is most strongly influenced by the advice of the ustadz/ clergy. Lowest indicator is subculture factor, with an average value of 52.0. It is addressing some people there who are affected by culture, because the virulence factors of the self, or as admitted to the defense of the religion. Some people are affected by their social class in deciding to become Islamic bank's customers. When compared with indicators of the respondents' answers to the items culture factor that only 52.0, social class more items affecting rural communities in deciding to become a customer. These results suggest that cultural factors influence the society was not so. Culture there is not really influence the community in becoming Islamic 
bank's customer, because only a small proportion of people who are affected by culture invillage.

Second is the social factor. The response from the villagers about the factors that influence people to become Islamic bank's customers on social factors based on the results obtained data collection are as follows: Data can be seen that the factor indicator of Reference, the majority of people who disagree is $40 \%$, while $27 \%$ of people stated strongly disagree, have shown that there is a majority of people who are not affected by the reference factors in rural communities. Reference group in here is among friend and the people closest to them. Compared with people who claim to agree as much as $17 \%$, and $10 \%$ said strongly agree, this indicates that the reference factors influence the decision of a person in becoming Islamic bank's customer is weakness. It can be seen that the indicators of the family, $47 \%$, the majority of people agree that the family had influence, $20 \%$ of people stated strongly agree, this shows that the majority of the communities affected by their family. Compared by people who disagree and strongly disagree is $30 \%$ and $3 \%$. It is much less as compared to respondents who answered agree, it means more people are affected by many factors in deciding their families to become customers of Islamic banks. Data can be seen that the respondents lies in the role and status indicators, 33\% of respondents agreed, 13\% of respondents strongly agreed with the stated percentage of $13 \%$. This indicated that there are some people who are affected because of their social status in society that caused them to become Islamic bank's customers. While respondents disagree as much as $30 \%$ of respondents stated and strongly disagree with the percentage of $7 \%$. It is addressed that there are some people who do not care about their status and role in society, so it does not affect the role and status in the community choose to be bank's customers. Respondents answer hesitation is $17 \%$.

Table 4. Recapitulation of Social Factor

\begin{tabular}{|c|c|c|}
\hline No & $\begin{array}{c}\text { Remarks } \\
\text { Sub-Factor }\end{array}$ & Mean \\
\hline 1 & References Group & 60.0 \\
\hline 2 & Family & 70.0 \\
\hline 3 & Role and Statuses & 63.0 \\
\hline
\end{tabular}

Source : Data processed by authors, 2014

From Table 4, it can be seen recapitulation of village community feedback about the factors that influence people to become Islamic bank's customers on social 
factors. The highest indicator of respondents' answers lies in a family of items with an average value of 70.0, the sub variables of social factors included in either category. This indicated that the village communities affected by the social there be Islamic bank's customer. The social factor itself is most strongly influenced by their families. Family advice is affecting their decision in becoming customers of the bank.

Lowest indicator of respondents' answers to the factor of reference group with an average value of 60.0, indicating some people there who are affected by the reference group, ie those whose behaviour is always to look like and their role model or example to be decided in terms of the bank's customers. Indicator on the role and status of items with an average is 63.0, also showed some people a little affected by the status and their role in the community.

Third is the personal factor. Responses Kancana's villagers about the factors that influence people to become Islamic bank's customers on personal factors based on the results obtained data collection are as follows: Data can be seen that the indicators of age and stage of life cycle. Respondents disagree with the $33 \%$ and the percentage of respondents expressed strongly disagree as much as $13 \%$ as well. Comparable to respondents who agree and strongly agree is 33\% and $13 \%$. This indicated that the villagers there are some who are affected by age and stage of life cycle, in part there is no effect. As for the respondents who expressed undecided are 7 $\%$; and this number slightly. Data can be seen that the indicators work, respondents who disagree $44 \%$, respondents who expressed strongly disagree $3 \%$, while $23 \%$ of respondents agreed and $10 \%$ strongly agree those states. This condition is largely due to the work of the villagers are self-employed, so they are not tied to their job. They can determine which banking institutions in accordance with their wishes. The respondents were hesitant to answer as much as $20 \%$. Data can be seen on the state of economic indicators, respondents who had agreed as much as 33\%, and $10 \%$ said strongly agree. This indicated that some people argue that the economic situation was extremely influential decision to become customers of the bank. Only a small proportion of those who stated that $17 \%$ disagree and strongly disagree that states as much as $7 \%$. While the people who expressed doubt as much as 33\%. Apparently there are still many people who feel hesitant with their economic circumstances in determining banking institutions which they would choose. This is because the majority of village people's livelihoods are businessmen, so their income is invested back in the business. Data can be seen that the sub variables of personal factors, the life style indicators, $37 \%$ of respondents disagree and strongly disagree were expressed by $17 \%$. This is because the villagers are not the type of people who are accustomed to a lifestyle change, respondents who agree as much as $33 \%$, and that states could not agree $10 \%$. It is claimed that there are some people who are affected 
because of his lifestyle. While doubtful, that the decision take effect life style is $3 \%$. Data can be seen that the influence of personality and self-concept indicators, $36 \%$ of respondents agreed there is the influence of personality and self-concept indicators, $11 \%$ of people stated strongly agree. Compare with people who disagree and strongly disagree, respectively $43 \%$ and $3 \%$. This shows that the majority of people affected by their personality in deciding to become customers of Islamic banks. The last factor in deciding the choice is based on respondent itself. Therefore, personal factors with indicators of personality and self-concept are impacting on the communities in the decision to become Islamic bank's customers.

Table 5. Recapitulation of Personal Factor

\begin{tabular}{ccc}
\hline No & $\begin{array}{c}\text { Remarks } \\
\text { Sub-Factor }\end{array}$ & Mean \\
\hline 1 & Age and Stage in The Life Cycle & 62.7 \\
2 & Occupation & 58.7 \\
3 & Economic Circumstances & 64.7 \\
4 & Life Style & 56.7 \\
5 & Personality and Self-Concept & 64.0 \\
\hline
\end{tabular}

Source : Data processed by authors, 2014

From Table 5, it can be seen recapitulation of village community feedback about the factors that influence people to become Islamic bank's customers on personal factors. The highest indicator of respondents' answers on the state of the economy subfactors with an average value of 64.7 then enter either category. This indicated that the village communities affected by their personal factors in becoming Islamic bank's customer. Although there are factors that influence the decision making, but the deciding factor is itself.

Lowest indicator of respondents' answers to the lifestyle subfactor with an average value 56.7. It is addressing some people have argued that lifestyle factors influence the decision not determining an option, as well subfactors jobs with an average 58.7 when viewed, this job is categorized simply, it means people are not so affected by their work in deciding to become a customer, especially since the majority of the villagers are entrepreneurs so they are not tied to their place of work. In addition, the average value of personality and self concept; age and stage in the life cycle subfactors, respectively, are 64.0 and 62.7. This show both subfactor has a good effect in a person decides to become Islamic bank's customers.

Fourth is the psychological factor. Responses the Kancana's villagers about the 
factors that influence people to become Islamic bank's customers in the psychological factors based on the results obtained data collection are as follows: Data can be seen that the sub variables of psychological factors, the indicators of motivation, respondents disagree and strongly disagree that motivation has an influence on the decision to become bank's customers is $46 \%$ and $17 \%$. It show that the villagers although given the motivation to be Islamic bank's customer, but has no effect. Only asmall proportion of those who agree and strongly agreed, respectively is $7 \%$ and $13 \%$, and respondents were undecided is $17 \%$. This indicated that the rural population is not affected by motivation to become Islamic banks customers. As for those who expressed hesitation due to the ignorance factor towards Islamic banking institutions. Data can be seen that the sub variables of psychological factors, the perception indicator, respondents disagree and strongly disagree states respectively are $33 \%$ and $10 \%$, the data showed that the majority of the rural population is affected by the perception of banking institutions sharia, only a few of those who agree and strongly agree, respectively is $27 \%$ and $13 \%$. While some people undecided as much as $13 \%$. Data can be seen that the sub variables ofpsychologicalfactors, indicators ofknowledge, $43 \%$ of respondents stated that states disagree and strongly disagree as much as $7 \%$. Respondents who agreed and strongly agreed respectively is $20 \%$ and $10 \%$, where as others expressed doubt as much as $20 \%$ as well. This indicated that village communities are not affected by the increasing knowledge of the different banking institutions through the spread of information. Data can be seen that the sub variables of psychological factors, trust and attitudes establishment indicator, respondents who disagree with the trust and attitudes of the establishment as much as $13 \%$, and $13 \%$ strongly disagreed, while respondents said strongly agree and agree respectively with the percentage of $23 \%$ and $27 \%$, and the latter is expressed doubt with the percentage of $23 \%$. This indicated that the villager is agreed, that the establishment of trust and attitudes influence the person's decision to become Islamic bank's customers.

Table 6. Recapitulation Psychological Factors

\begin{tabular}{clc}
\hline No & \multicolumn{1}{c}{$\begin{array}{c}\text { Remarks } \\
\text { Sub-Factors }\end{array}$} & Mean \\
\hline 1 & Motivation & \\
2 & Perception & 50.7 \\
3 & Knowledge & 57.3 \\
4 & Establishment Trust and Attitude & 56.7 \\
\hline
\end{tabular}

Source : Data processed by authors, 2014 
From table 6, it can be seen recapitulation responses Kancana's villagers about the factors that influence people to become Islamic bank's customers on psychological factors. The highest indicator of respondent's answers to the sub factors are confidence and attitude with an average value of 66.7, then categorized as good. This indicated that the village communities affected by their psychological factors in becoming Islamic bank's customer. They will be the Islamic bank's customer if it starts to grow confidence and attitude of the establishment. Lowest indicators in the motivation of respondents with an average value of 50.7. It is addressed that the sub-factors of motivation so that they become customers of minimal influence. It is also influenced due to Islamic banking institutions is still limited existence, and it affects people's motivation patterns of Islamic banking institutions. While indicators of the respondent's answers to the sub factors knowledge is average of 56.7 , include enough category, in the sense that people are starting to know about Islamic banking. People are starting to know enough about Islamic banking and influence. Last indicator on sub factors perception of respondents with an average of 57.3 is categorized enough.

\section{Conclusion}

Based on the analysis and discussion are carried out, it can be obtained several conclusions, among others. First, jobs or livelihoods of rural people, correspond in general, rural livelihood is farming but not least also the livelihood trade or self-employed, because some areas agriculture can not be separated from business activities. Therefore, the income level of villagers relatively small and depends on the condition of the rural economy.

Second, the factors that most influence to become the Islamic bank's customer in Kancana's village was sub factors family on social factors, in rural communities, family is very important when some one will make a decision. Similarly, sub-cultural factors on cultural factors such as factor nationalities, religions, racial groups, and geographic regions, influence the decision of the villagers. Furthermore, who has a strong influence of rural communities is establishment trust and attitude on psychological factors, and economic circumstances and self concept (personal factors).

\section{Reference}

Agung, N.B. 2005. Statistical Methods Using SPSS. Yogyakarta: Andi Offset. Antonio, M.S. 2001. Islamic Bank: Theory and Practice. Jakarta: Gema Insani Press. Assauri, S. 2004. Marketing Management. Jakarta: Rajawali Press. Ayub, M. 2007. Understanding Islamic Finance. New York: John Wiley \& Sons 
Ltd.

Budisantoso T \& S. Triandaru. 2006. Bank and Other Financial Institutions. Jakarta: Salemba Empat.

Hawkins, R.J. \& C. Best. 2001. Consumer Behavior Building Marketing Strategy, 8th ed. Boston: McGraw Hill.

Iqbal, M \& T. David. 2002. Islamic Banking and Finance: New Perspective on ProfitSharing and Risk. New Jersey: Edward Elgar Publishing Inc

Istijanto. 2009. Practical Application on Marketing Research. Jakarta: Gramedia Pustaka Utama.

Kotler, P. 2005. Marketing Management. New York: Prentice Hall.

Kotler, P \& K.L. Kellet. 2008. Marketing Management. Jakarta: Erlangga.

Loudon, D.L. \& A.J.D. Bitta. 1993. Consumer Behavior, 4th Edition. New York: McGraw-Hill International Edition.

Muhammad. 2005. Financial Management in Islamic Banks. Yogyakarta: AMP YKPN.

Qardhawi, Y. 1997. The Role of Value and Moral on Islamic Economic. Jakarta: Robbani Press.

Riduwan. 2006. Basic Statistic. Bandung: Alfabeta.

Sheth, J.N. \& B. Mittal. 2004. .Consumer Behavior: A Managerial Perspective. 2nd edn. Singapore: Thomson South-Western.

Subagyo, et.al 2002. Bank and Other Financial Institution. Yogyakarta: STIE Publishing.

Sugiyono. 2008. Quantitative, Qualitative and R\&D Reseacrh Method. Bandung: Alfabeta.

Sujianto. 2009. Statictics Using SPSS. Jakarta: Prestasi Pustaka Publisher.

Sulianto. 2006. Data Analysis on Marketing. Bogor: Ghalia Indonesia.

Swastha, B. \& I. Sukotjo. 1995. An Introduction to Modern Business. Yogyakarta: Liberty.

Umar, H. 2004. The Research Method for Thesis. Jakarta: RajaGrafindo Persada. 